\title{
Technological and electronic communication device addiction and its associated physical and psychosocial comorbidity among obese and overweight children aged 10 to 14 years, who attend the nutrition clinic at Colombo North Teaching Hospital
}

\author{
*Denipitiyage Thanura Udayanga Denipitiya ${ }^{1}$, Mary Antonette Manel Fernando ${ }^{2}$, Pujitha \\ Wickramasinghe ${ }^{3}$
}

Sri Lanka Journal of Child Health, 2020; 49(4): 375-382

\begin{abstract}
Background: Addiction to technological and electronic communication devices is the emerging trend among adolescents. Studies reveal a relationship between such addiction and obesity leading to physical and psychosocial morbidity.
\end{abstract}

Objectives: To assess the addiction to technological and electronic communication device and its associated physical and psychosocial comorbidity among 10 to 14 year old obese and overweight children attending the nutrition clinic at Colombo North Teaching Hospital.

Method: A clinic based cross sectional descriptive study was conducted among 406 overweight and obese children who attended the nutrition clinic at Colombo North Teaching Hospital, using an interviewer administered questionnaire.

Results: Prevalence of technological and electronic communication device addiction among the overweight and obese adolescent population in 1014 years was $41.4 \%$. Cartoon was the highest addicted programme among television (TV) addicted group at $65.6 \%$, whereas games were the most interested programme in non-TV addicted group which was $73.3 \%$. Education of the carer, employment status of the carer, place of device usage and number of hours spent in outdoor activities had affected the screen time and

\footnotetext{
${ }^{1}$ Senior Registrar in Paediatrics, Colombo North Teaching Hospital, Ragama, Sri Lanka, ${ }^{2}$ Consultant Paediatrician, Private Sector, Negombo, Sri Lanka, ${ }^{3}$ Senior Professor, Department of Paediatrics, Faculty of Medicine, University of Colombo, Sri Lanka

*Correspondence: thanuratud@gmail.com

orcid.org/ 0000-0003-4437-5405
}

(Received on 18 January 2020: Accepted after revision on 28 February 2020)

The authors declare that there are no conflicts of interest

Personal funding was used for the project.

Open Access Article published under the Creative

Commons Attribution CC-BY (C) (i) technology addiction significantly $(p<0.05)$. Several physical and psychosocial morbidities were identified in a significant association to the technology addiction in obese and overweight adolescents $(\mathrm{p}<0.05)$.

Conclusions: Technological and electronic communication device addiction has adversely affected the behavioural and physical health of obese and overweight adolescents in addition to metabolic derangements, augmented by many other factors.

DOI: http://dx.doi.org/10.4038/sljch.v49i4.9270

(Key words: Obesity and overweight, technology, addiction, morbidity)

\section{Introduction}

Addiction to technological and electronic communication devices is an emerging trend seen in adolescents. Technology addiction is defined as compulsive/ impulsive online and /or offline computer / mobile device usage despite negative consequences to the user of the technology ${ }^{1}$. It refers to the compulsive, uncontrollable dependence to such a degree that cessation causes severe emotional, mental and psychological reactions ${ }^{2,3}$. Young has made eight criteria for the diagnosis of technology addiction based on four main components of addiction according to Diagnostic and Statistical Manual of mental disorders $-\mathrm{V}(\mathrm{DSM} \mathrm{V})^{1}$. The above criteria were categorized and modified by Beard ${ }^{4}$. According to him, all of the first five criteria and one of the last three criteria made by Young are required for the diagnosis of technology addiction. The first five criteria could account for numerous behaviours that would not necessarily classify as an addiction and the last three criteria are separated from the others as these criteria impact the pathological technology user's ability to cope and function and also impact interactions with other people in his or her life ${ }^{4}$.

Handling of technological devices for nonacademic purposes is rising. It affects academic performances, real life experiences and social engagement. Therefore, not only the social network sites, but also the technological dependency can 
contribute to a behavioural change thus leading to addiction to these devices. Common hedonic mechanisms may explain a relationship between obesity and addiction ${ }^{5}$. The prevalence of overweight among adolescents has increased over the recent decades and its harmful effects are more evident with time as it progresses to adult obesity leading to development of non-communicable diseases $^{6-8}$. According to the estimates of the World Health Organization (WHO), by the year 2020, non-communicable diseases will account for approximately three quarters of deaths in the developing world ${ }^{9}$. Sri Lanka is in a state of accelerated demographic, nutritional and epidemiological transition, in parallel to the socioeconomic development and urbanization. As a result, the unhealthy dietary practices and life style changes make the adolescent population overweight and obese. Research has been done on the addiction of technology among different groups of young adults and adolescents and related to body mass index $(\mathrm{BMI})^{10-12}$. Furthermore, there were some studies looking at screen time and obesity ${ }^{13}$.

Studies have identified some physical and psychosocial consequences of dependency of technology and its addiction in youngsters ${ }^{14}$. Behavioural symptoms were considered as appearing on a high while using electronic devices, avoiding friends and family, not getting enough sleep as compared to normal bed time, denying actual usage time spent on technological devices, avoiding activities that were once enjoyable to them. Physical morbidity patterns were considered as headache (non-sinister) with a frequency of at least once a week, whereas, vision problems were accounted to either new changes in visual acuity, eye strain or tearing. Furthermore, noninflammatory type aches and stiffness, numbness and pain in the palms and fingers were considered as physical ailments with technology usage. This study was conducted to assess the technology addiction in obesity and overweight and its associated factors.

\section{Objectives}

To describe the technological and electronic communication device addiction and its associated physical and psychosocial comorbidity among obese \& overweight children aged 10-14 years, who attend the nutrition clinic at Colombo North Teaching hospital.

\section{Method}

This cross sectional descriptive study was carried out in Colombo North Teaching Hospital during a period of six months in 2017/2018. The study sample included obese and overweight patients in the age group of 10-14 years who got registered randomly, out of the wide age range of registered children at the nutrition clinic. Sampling frame was the daily clinic attendance register, including both new and already being followed up patients without repetition. Consecutive patients who met the inclusion criteria were recruited into the study. Calculated sample size was 384 as per formula by Lwanga and Lameshow. 412 patients were recruited into study, but only 406 patients responded. Children below 10 years or above 14 years were not recruited to study. Furthermore, children attending the clinic without a parent/ guardian, children with previously diagnosed developmental disorders, children with severe visual or hearing impairment which cannot be corrected and children with obesity due to congenital, heritable, neurological or endocrinology disorders were excluded from the study. Further, all children who attended the clinic were assumed to have access to at least one of the electronic device during the past 3 months. The electronic devices considered were, mobile phones, laptop, tablet computer, desktop computer, and TV.

The questionnaire was developed in consultation with an expert panel and reviewing of literature. It included socio-demographic details, information about technological device usage, physical/ psychosocial morbidity and addiction to screen device. Sex and age specific BMI criteria had been defined according to the WHO standards ${ }^{15}$. Overweight had been based on BMI for age $>+1$ standard deviations (SD) from the median and $\leq$ $+2 \mathrm{SD}$, whereas obese children had a BMI for age $>$ $+2 \mathrm{SD}$ of the median ${ }^{15}$. Questionnaire was made according to Beard to assess technology addiction within the local setting, by modifying the Young's internet addiction screening criteria that has been outlined in published literature ${ }^{4,16}$. Beard modification consisted of eight criteria which include behavioral, psychological and social factors with a one mark for each positive criterion. Score $\geq$ 6 including initial five consecutive criteria plus, one or more in the final three criteria, were taken as addiction and unable to score as above is considered non-addiction ${ }^{4}$.

A pilot study was conducted using the pretested questionnaire, in the patients who attended the same nutrition clinic, to assess feasibility of applying it in the study. An interviewer administered questionnaire was used by the main investigator to obtain the data from parents/guardians of the index children following informed written consent. Ethical clearance was obtained from the ethics review committee, Post Graduate Institute of Medicine, University of Colombo, while the administrative approval was taken from the hospital authorities. 
The data analysis was conducted according to the Statistical Package for the Social Sciences (SPSS, version 23) for Windows. The pattern of device usage was described in terms of the type of device, duration of use and purpose of the device use. All variables were described in terms of frequency and proportion. Factors associated with addiction to technological devices were analysed using Chi square test. Statistically significant difference was calculated at $\mathrm{p}<0.05$ at the confidence level of $95 \%$.

\section{Results}

There were 412 eligible patients recruited for the study and only 406 responded with a response rate of $98.5 \%$. Their sociodemographic data and their medical characteristics are illustrated in Table 1. Males comprised the majority of the sample with 221 (54.4\%), while females comprised 185 (45.6\%). Average age of males was 12 years and 3 months and females 12 years and 1 month. Majority (57.4\%) of patients were overweight.

Table 1: Distribution of study population according to sociodemographic and medical characteristics

\begin{tabular}{|l|c|c|c|}
\hline Characteristics & $\begin{array}{c}\text { Male } \\
\text { n }\end{array}$ & $\begin{array}{c}\text { Female } \\
\text { n }\end{array}$ & $\begin{array}{c}\text { Total } \\
\text { n (\%) }\end{array}$ \\
\hline School & & & $181(44.6)$ \\
Government - National & 110 & 11 & $206(50.7)$ \\
Government - Non National & 97 & 05 & $19(04.7)$ \\
Private & 14 & 164 & $351(86.4)$ \\
\hline Ethnicity & 187 & 02 & $05(01.2)$ \\
Sinhala & 03 & 17 & $48(11.8)$ \\
Tamil & 31 & 02 & $02(0.5)$ \\
Muslim & 0 & 88 & $184(45.3)$ \\
Other & & 63 & $158(38.9)$ \\
\hline Area of residence & 96 & 34 & $64(15.8)$ \\
Urban & 95 & & $192(47.3)$ \\
Sub Urban & 30 & 97 & $211(52)$ \\
Rural & & 87 & $03(0.7)$ \\
\hline Number of children in the family & 95 & 01 & $173(42.6)$ \\
1 & 124 & & $233(57.4)$ \\
\hline
\end{tabular}

Table 2 shows the prevalence of addiction and the pattern of addiction to technological devices among the study group. Technology addiction was analysed according to the responses from parents / guardians. The proportion of addiction among the study group was $168(41.4 \%)$. Out of the addicted group, $93(55.4 \%)$ of adolescents were addicted to TV. Cartoon was the most addicted TV programme $(65.6 \%)$, while the non-TV addicted group was most attracted to games $(73.3 \%)$.

Table 3 shows the identified morbidity patterns in relation to the technology addiction. The available data showed an increasing trend of physical and behavioural morbidity with technology addiction. While $47.6 \%$ of children with technological addiction had behavioural morbidity, only $36.1 \%$ of adolescents without technology addiction had identified behavioural morbidity, which is statistically significant $(p<0.05)$. Furthermore, $48.2 \%$ of addicted adolescents had physical morbidity, whereas $62.6 \%$ of adolescents in the study group without the technology and telecommunication device addiction did not have the physical morbidity, which is statistically significant $(\mathrm{p}<0.05)$.

Furthermore, there were statistically significant relationships between the technological device addiction and behavioural morbidities of appearing on high while using the device, avoiding family and friends, denial of actual state of using the device and avoiding activities which were earlier enjoyable to them $(\mathrm{p}<0.05)$. Similarly, the data in this study showed significant relationship between the addiction to technological device and the presences of physical morbidities of headache and vision problems $(p<0.05)$. There were no statistically significant relationships between the addiction and the lack of sleep, aches and stiffness and numbness of hand $(\mathrm{p}>0.05)$. 
Table 2: Prevalence of addiction and other identified patterns of technology addiction

\begin{tabular}{|l|c|}
\hline \multicolumn{1}{|c|}{ Characteristic } & Number ( \% ) \\
\hline Addiction & $238(58.6)$ \\
No & $168(41.4)$ \\
Yes & \\
\hline Screen time & $84(20.7)$ \\
$<1$ hour & $177(43.6)$ \\
$1-3$ hours & $145(35.7)$ \\
$>3$ hours & \\
\hline Commonest used device in children with technology addiction & $10(05.9)$ \\
Personal computers & $05(03.0)$ \\
Laptop computers & $14(08.3)$ \\
Tablet (Android) & $39(23.2)$ \\
Mobile phones & $07(04.2)$ \\
Game devices & $93(55.4)$ \\
Television & \\
\hline Addicted programme (except television) & $00(0)$ \\
Academic purposes & $06(08.0)$ \\
Communication with relatives and friends & $10(13.3)$ \\
Entertainment & $00(0)$ \\
News reading & $55(73.3)$ \\
Games & $04(05.3)$ \\
Social media & \\
\hline Addicted programme in television & $15(16.1)$ \\
Tele drama & $05(05.4)$ \\
Movie & $02(02.1)$ \\
Educational/ Documentary & $61(65.6)$ \\
Cartoons & $10(10.7)$ \\
Sports &
\end{tabular}

Table 3: Morbidity patterns with technology addiction

\begin{tabular}{|c|c|c|c|c|c|c|c|}
\hline \multirow{3}{*}{\multicolumn{3}{|c|}{ Pattern of morbidity }} & \multicolumn{4}{|c|}{ Addiction } & \multirow{3}{*}{$\mathbf{p}^{*}$} \\
\hline & & & \multicolumn{2}{|c|}{ Present } & \multicolumn{2}{|c|}{ Absent } & \\
\hline & & & $\mathbf{n}$ & $\%$ & $\mathrm{n}$ & $\%$ & \\
\hline \multirow{2}{*}{\multicolumn{2}{|c|}{ Behavioural morbidity }} & Yes & 80 & 47.6 & 86 & 36.1 & \multirow[t]{2}{*}{0.020} \\
\hline & & No & 88 & 52.4 & 152 & 63.9 & \\
\hline \multirow{2}{*}{\multicolumn{2}{|c|}{ Physical morbidity }} & Yes & 81 & 48.2 & 89 & 37.4 & \multirow[t]{2}{*}{0.030} \\
\hline & & No & 87 & 51.8 & 149 & 62.6 & \\
\hline \multirow{10}{*}{$\begin{array}{l}\text { Behavioural } \\
\text { morbidity }\end{array}$} & \multirow[t]{2}{*}{ Appearing on a high while using the devices } & Yes & 50 & 29.8 & 46 & 19.3 & \multirow[t]{2}{*}{0.015} \\
\hline & & No & 118 & 70.2 & 192 & 80.7 & \\
\hline & \multirow[t]{2}{*}{ Avoid friends \& family } & Yes & 31 & 18.5 & 23 & 09.7 & \multirow[t]{2}{*}{0.010} \\
\hline & & No & 137 & 81.5 & 215 & 90.3 & \\
\hline & \multirow{2}{*}{ Not enough sleep } & Yes & 40 & 23.8 & 40 & 16.8 & \multirow{2}{*}{0.081} \\
\hline & & No & 128 & 76.2 & 198 & 83.2 & \\
\hline & \multirow[t]{2}{*}{ Denial of actual status of usage of devices } & Yes & 48 & 28.6 & 46 & 19.3 & \multirow{2}{*}{0.030} \\
\hline & & No & 120 & 71.4 & 192 & 80.7 & \\
\hline & \multirow{2}{*}{$\begin{array}{l}\text { Avoid activities which were previously } \\
\text { enjoyable }\end{array}$} & Yes & 56 & 33.3 & 55 & 23.1 & \multirow[t]{2}{*}{0.023} \\
\hline & & No & 112 & 66.7 & 183 & 76.9 & \\
\hline \multirow{8}{*}{$\begin{array}{l}\text { Physical } \\
\text { morbidity }\end{array}$} & \multirow{2}{*}{ Headache } & Yes & 53 & 31.5 & 52 & 21.8 & \multirow{2}{*}{0.028} \\
\hline & & No & 115 & 68.5 & 186 & 78.2 & \\
\hline & \multirow{2}{*}{ Vision problems } & Yes & 41 & 24.4 & 37 & 15.5 & \multirow{2}{*}{0.026} \\
\hline & & No & 127 & 75.6 & 201 & 84.5 & \\
\hline & \multirow{2}{*}{ Aches \& stiffness } & Yes & 17 & 10.1 & 13 & 05.5 & \multirow[b]{2}{*}{0.077} \\
\hline & & No & 151 & 89.9 & 225 & 94.5 & \\
\hline & \multirow[t]{2}{*}{ Numbness \& pain in palms \& fingers } & Yes & 13 & 07.8 & 09 & 03.8 & \multirow[t]{2}{*}{0.083} \\
\hline & & No & 155 & 92.3 & 229 & 96.2 & \\
\hline
\end{tabular}


Table 4 shows the relationship between the variables, which could have an involvement with the presence of technology addiction. There was a statistically significant relationship between the technological device addiction and the education of the carer, employment status of the carer and place of using the device $(\mathrm{p}<0.05)$. Similarly, the screen time also showed a statistically significant relationship with the above variables $(\mathrm{p}<0.05)$. Furthermore, the number of hours involved in outdoor activities was significantly related to the technology addiction and screen time $(\mathrm{p}<0.05)$.

Gender, school type or area of residence did not have a significant relationship with technological device addiction or the screen time $(\mathrm{p}>0.05)$.

Table 4: Factors associated with technology addiction and screen time

\begin{tabular}{|c|c|c|c|c|c|c|c|}
\hline \multirow[t]{2}{*}{ Variable } & \multicolumn{2}{|c|}{ Technology addiction } & \multirow[t]{2}{*}{$\mathbf{p}^{*}$} & \multicolumn{3}{|c|}{ Screen time (hours) } & \multirow[t]{2}{*}{ p* } \\
\hline & $\begin{array}{c}\text { Present } \\
\text { n (\%) }\end{array}$ & $\begin{array}{c}\text { Absent } \\
\text { n (\%) }\end{array}$ & & $\begin{array}{c}<1 \\
\mathrm{n}(\%)\end{array}$ & $\begin{array}{c}1-3 \\
\text { n }(\%) \\
\end{array}$ & $\begin{array}{c}>3 \\
\text { n (\%) }\end{array}$ & \\
\hline $\begin{array}{l}\text { Gender } \\
\text { Male } \\
\text { Female }\end{array}$ & $\begin{array}{l}97(57.7) \\
71(42.3)\end{array}$ & $\begin{array}{l}124(52.1) \\
114(47.9)\end{array}$ & 0.261 & $\begin{array}{l}42(50.0) \\
42(50.0)\end{array}$ & $\begin{array}{l}96(54.2) \\
81(45.8)\end{array}$ & $\begin{array}{l}83(57.2) \\
62(42.8)\end{array}$ & 0.569 \\
\hline $\begin{array}{l}\text { School type } \\
\text { Government - national } \\
\text { Government - non national } \\
\text { Private }\end{array}$ & $\begin{array}{l}68(40.5) \\
92(54.8) \\
08(04.8) \\
\end{array}$ & $\begin{array}{l}113(47.5) \\
114(47.9) \\
11(04.6) \\
\end{array}$ & 0.368 & $\begin{array}{l}38(26.2) \\
40(47.6) \\
06(07.1)\end{array}$ & $\begin{array}{l}86(48.6) \\
84(47.5) \\
07(03.9)\end{array}$ & $\begin{array}{l}57(39.3) \\
82(56.6) \\
06(04.1)\end{array}$ & 0.351 \\
\hline $\begin{array}{l}\text { Area of residence } \\
\text { Urban } \\
\text { Sub urban } \\
\text { Rural } \\
\end{array}$ & $\begin{array}{l}76(45.2) \\
73(43.5) \\
19(11.3) \\
\end{array}$ & $\begin{array}{l}108(45.4) \\
85(35.7) \\
45(18.9) \\
\end{array}$ & 0.077 & $\begin{array}{l}41(48.8) \\
33(39.3) \\
10(11.9) \\
\end{array}$ & $\begin{array}{l}87(49.1) \\
62(35.0) \\
28(15.8) \\
\end{array}$ & $\begin{array}{l}56(38.6) \\
63(43.4) \\
26(17.9) \\
\end{array}$ & 0.296 \\
\hline $\begin{array}{l}\text { Education of the carer } \\
\text { Less than Grade } 6 \\
\text { Grades 6-9 } \\
\text { Ordinary Level } \\
\text { Advanced Level } \\
\text { Higher Education }\end{array}$ & $\begin{array}{l}25(14.9) \\
45(26.8) \\
74(44.0) \\
14(08.3) \\
10(06.0)\end{array}$ & $\begin{array}{l}12(05.0) \\
79(33.2) \\
109(45.8) \\
22(09.2) \\
16(06.7)\end{array}$ & 0.017 & $\begin{array}{l}06(07.1) \\
35(41.7) \\
32(38.1) \\
07(08.3) \\
04(04.8)\end{array}$ & $\begin{array}{l}10(05.6) \\
51(28.8) \\
83(46.9) \\
17(09.6) \\
16(09.0)\end{array}$ & $\begin{array}{l}21(14.5) \\
38(26.2) \\
68(46.9) \\
12(08.3) \\
06(04.1)\end{array}$ & 0.036 \\
\hline $\begin{array}{l}\text { Employment of carer } \\
\text { No } \\
\text { Yes }\end{array}$ & $\begin{array}{l}59(35.1) \\
109(64.9) \\
\end{array}$ & $\begin{array}{l}111(46.6) \\
127(53.4) \\
\end{array}$ & 0.020 & $\begin{array}{l}47(56.0) \\
37(44.0) \\
\end{array}$ & $\begin{array}{l}74(41.8) \\
103(58.2) \\
\end{array}$ & $\begin{array}{r}49(33.8) \\
96(66.2) \\
\end{array}$ & 0.005 \\
\hline $\begin{array}{l}\text { Place of use } \\
\text { Home (Common Area) } \\
\text { Bed Room } \\
\text { School } \\
\text { Travel } \\
\text { Other }\end{array}$ & $\begin{array}{l}79(47.0) \\
63(37.5) \\
02(01.2) \\
04(02.4) \\
20(11.9)\end{array}$ & $\begin{array}{l}107(45.0) \\
61(25.6) \\
33(13.9) \\
20(08.4) \\
17(07.1)\end{array}$ & 0.000 & $\begin{array}{l}27(31.1) \\
19(22.6) \\
22(26.2) \\
12(14.3) \\
04(04.8)\end{array}$ & $\begin{array}{l}106(59.9) \\
47(26.6) \\
04(02.3) \\
06(03.4) \\
14(07.9)\end{array}$ & $\begin{array}{l}53(36.6) \\
58(40.0) \\
09(06.2) \\
06(04.1) \\
19(13.1)\end{array}$ & 0.000 \\
\hline $\begin{array}{l}\text { Hours of outdoor activities } \\
<1 \\
1-2 \\
>2\end{array}$ & $\begin{array}{l}106(63.1) \\
49(29.2) \\
13(07.7)\end{array}$ & $\begin{array}{l}120(50.4) \\
80(33.6) \\
38(16.0)\end{array}$ & 0.013 & $\begin{array}{l}33(39.3) \\
31(36.9) \\
20(23.8)\end{array}$ & $\begin{array}{l}101(57.0) \\
62(35.0) \\
14(07.9)\end{array}$ & $\begin{array}{l}92(63.5) \\
36(24.8) \\
17(11.7)\end{array}$ & 0.000 \\
\hline
\end{tabular}

*From Chi square test

\section{Discussion}

In this study $41.4 \%$ obese and overweight adolescents were addicted to technological devices; while $43.6 \%$ of study population had a screen time of $1-3$ hours/ day, $35.7 \%$ had more than 3 hours/ day. In contrast, a non-experimental cross sectional study in 370 students attending 4 elementary schools in Korea showed a significant association of screen time with increased BMI. Meanwhile, $45.7 \%$ of children were reported to have a screen time of $1-2.9$ hours/day and $8.9 \% 3$ or more hours per day ${ }^{18}$. A study in USA showed that 8-18 yearold children spend about 4.5 hours per day on TV, videotapes and playing video games ${ }^{19}$.

Studies on technology addiction among obese adolescents have not been done in Sri Lanka. International studies show a significant relationship between screen time and prevalence of obesity, prevalence increasing by $2 \%$ for each additional hour of TV viewing ${ }^{20,21}$. In adolescents, technology use has been linked to high energy intake in the absence of hunger while using screen. Furthermore, advertisements of unhealthy foods through unrestricted internet, TV and mobile applications also promote the current eating habits ${ }^{22-24}$.

In this study, some identified behavioural and physical morbidities were significantly associated with technology addiction and screen time. Appearing high while using technological devices, avoiding friends and family, denial of actual status of device usage, avoiding activities previously enjoyable, headache and visual problems were significantly associated with technology addiction but there was no significant relationship with aches/ stiffness and sleep. A study in Norwegian teens showed that the combination of more TV, video and computer use lead to more back pain and headache ${ }^{25}$. An American study showed more total ill-being, more attention problems and physical problems in children who used more technology ${ }^{26}$. 
Kraut et al revealed that social networks and TV viewing have an impact on physical inactivity as well as on social withdrawal and low psychological wellbeing ${ }^{27}$. This general response pattern was partially confirmed by the study by Wastlund et al, which showed an increased tendency for less psychological wellbeing among people with internet addiction $^{28}$. Meanwhile a north Indian study by Meena et al showed that use of excess social network had higher rate of depression, anxiety and stress score ${ }^{29}$. In contrast to our findings, a study by Foley et al showed worse sleep quality in children viewing TV during the last $90 \mathrm{~min}$ before sleep ${ }^{30}$. Unfortunately, due to lack of studies on technology addiction in adolescents, information on this topic is scanty.

In considering factors associated with technological device addiction, educational status of caregiver and employment status of carer were significantly associated with technological device addiction in obese and overweight adolescents. Similarly, a study by Furthner et al showed significant correlation between lower parental education and longer screen time ${ }^{31}$. Our study did not show any significant association between technological addiction and gender, school type or area of residence of obese and overweight adolescents.

There were statistically significant relationships between the place of using the device and the addiction as well as the screen time. A study done in USA by Dennison et al showed that almost $40 \%$ of children had a TV in their bedroom and they had more tendency to become overweight by spending more time (4.6 hours/ week) on viewing TV than children without a TV in their bedroom ${ }^{32}$.

Investigators have hypothesized that watching the $\mathrm{TV}$ is responsible for making a person obese by one or more of three possible ways such as displacement of physical activity, increased calorie intake while watching TV or due to the effects of advertising and reduced resting metabolism ${ }^{33}$. Similarly, the results of our study among the obese and overweight adolescents revealed that the relationship between technological device addiction as well as the screen time is statistically significant with the number of hours spent on outdoor activities. TV, movies, video games, mobile phones and computer networks have assumed an important central role in children's lives which invariably influence the child health including social isolation, violence, substance abuse and sexual behaviours ${ }^{34}$. Therefore, it's essential to take some steps to minimize this social catastrophe.

There were a few limitations to the study. The data were collected from a government hospital where the social status and the financial situation of the family would not be fair representation of society. Therefore, generalisation of the results may be limited. However, since data from a relatively lower socioeconomic strata show that addiction of technological and communication devices is fairly high, it can be postulated that the condition would be worse in higher socioeconomic strata having more accessibility to such devices. Despite the limitations, findings in this study are significant for the care of obese and overweight adolescents with regard to the use of technological and electronic communication devices in Sri Lanka, and also to be taken into consideration in designing obesity programmes in the country. Technology addiction among children and adolescents is a new arena for clinical research. Local and international studies among adolescent group, especially in obese and overweight group are lacking. Further studies into this field and comparison with normal population can be used to analyse the situation and social impact in a wide range.

\section{Conclusions}

Addiction to use of electronic devices is a significant associated factor with overweight and obesity and it is related to several physical and psychosocial morbidities.

\section{Acknowledgements}

We thank to all the patients and caregivers who consented to participate in this study.

\section{References}

1. Block JJ. Issues for DSM-V: internet addiction. American Journal of Psychiatry 2008; 165:306-7. https://doi.org/10.1176/appi.ajp.2007.07101 556

PMid: 18316427

2. Wilson GT. Eating disorders, obesity and addiction. European Eating Disorders Review 2010; 18:341-51. https://doi.org/10.1002/erv.1048 PMid: 20821736

3. Giotakos O, Tsouvelas G, Spourdalaki E, Janikian M, Tsitsika A, Vakirtzis A. Internet gambling in relation to Internet addiction, substance use, online sexual engagement and suicidality in a Greek sample. International Gambling Studies 2017; 17(1): 20-9.

https://doi.org/10.1080/14459795.2016.125 1605

4. Beard KW, Wolf EM. Modification in the proposed diagnostic criteria for Internet 
addiction. Cyber Psychology \& Behavior 2001; 4:377-83.

https://doi.org/10.1089/1094931013002102

86

PMid: 11710263

5. Simon GE, Von Korff M, Saunders K, Miglioretti DL, Crane PK, van Belle G, et al. Association between obesity and psychiatric disorders in the US adult population. Archives of General Psychiatry 2006; 63(7):824-30.

https://doi.org/10.1001/archpsyc.63.7.824

PMid: 16818872 PMCid: PMC1913935

6. Ogden CL, Carroll MD, Curtin LR, McDowell MA, Tabak CJ, Flegal KM. Prevalence of overweight and obesity in the United States, 1999-2004. Journal of the American Medical Association 2006; 295(13):1549-55.

https://doi.org/10.1001/jama.295.13.1549

PMid: 16595758

7. Gortmaker SL, Must A, Perrin JM, Sobol AM, Dietz WH. Social and economic consequences of overweight in adolescence and young adulthood. New England Journal of Medicine 1993; 329(14):100812.

https://doi.org/10.1056/NEJM19930930329 1406

PMid: 8366901

8. Must A, Jacques PF, Dallal GE, Bajema CJ, Dietz WH. Long-term morbidity and mortality of overweight adolescents: a follow-up of the Harvard Growth Study of 1922 to 1935. New England Journal of Medicine 1992; 327(19):1350-5.

https://doi.org/10.1056/NEJM19921105327 1904

PMid: 1406836

9. World Health Organization. Global strategy for non-communicable disease prevention and control (draft). Geneva, Switzerland: World Health Organization, 1997. (Publication no. WHO/NCD/GS/97.1)

10. Lehtinen-Jacks S, Koivusilta L, Lintonen T. Use of information and communication technology and prevalence of overweight and obesity among adolescents. International Journal of Obesity 2005; 29(8): 925-33.

https://doi.org/10.1038/sj.ijo.0802994

PMid: 15925961
11. Young KS. (1998) Caught in the net. New York: John Wiley, pp. 12-120.

12. Canan F, Yildirim O, Ustunel TY, et al. The relationship between Internet addiction and body mass index in Turkish adolescents. Cyberpsychology, Behavior, and Social Networking 2014; 17(1), 40-5. https://doi.org/10.1089/cyber.2012.0733 PMid: 23952625

13. Dietz WH, Gortmaker SL. Do we fatten our children at the television set? Obesity and television viewing in children and adolescents. Pediatrics 1985; 75:807-12.

14. Young KS. Internet Addiction: The emergence of a new clinical disorder. Cyber Psychology \& Behavior 1998; 1(3) 237-44.

https://doi.org/10.1089/cpb.1998.1.237

15. www.cdc.gov/growthcharts, National Center for Health Statistics in collaboration with the National Center for Chronic Disease Prevention and Health Promotion (2000)

16. American Psychiatric Association, (2013).Diagnostic and statistical manual of mental disorders. 5th ed. Substance-Related and Addictive Disorders, Non-SubstanceRelated Disorders Gambling Disorder 312.31:585-589

https://doi.org/10.1176/appi.books. 9780890 425596

17. Lwanga SK, Lameshow S. (1991) Sample size Determination in Health Studies. WHO, Geneva

18. Ham OK, Sung KM, Kim HK. Factors associated with Screen Time among schoolage children in Korea. The Journal of School Nursing 2013; 29(6), 425-34. https://doi.org/10.1177/1059840513486483 PMid: 23598570

19. Roberts DF, Foehr UG, Rideout VJ, et al. Kids \& Media at the New Millennium: A comprehensive national analysis of children's media use. Menlo Park, CA, The Henry J. Kaiser Family Foundation, 1999

20. Dietz WH, Jr, Gortmaker SL. Do we fatten our children at the television set? Obesity and television viewing in children and adolescents Pediatrics 1985; 75(5): 
21. Obesity and television viewing in children and adolescents. Nutrition Reviews 1986; 44(1), 9-9.

https://doi.org/10.1111/j.17534887.1986.tb 07544.x

PMid: 3951765

22. Chaput JP, Visby T, Nyby S, Klingenberg L, Gregersen NT, Tremblay A, Sjödin A. Video game playing increases food intake in adolescents: a randomized crossover study. American Journal of Clinical Nutrition 2011; 93(6): 1196-203. https://doi.org/10.3945/ajcn.110.008680 PMid: 21490141

23. Lazarou C, Soteriades ES. Children's physical activity, TV watching and obesity in Cyprus: the CYKIDS study. European Journal of Public Health 2009; 20(1): 70-7. https://doi.org/10.1093/eurpub/ckp093 PMid: 19556383

24. Zhang T, Cai L, Ma L, Jing J, Chen Y, Ma J. The prevalence of obesity and influence of early life and behavioral factors on obesity in Chinese children in Guangzhou. BMC Public Health 2016; 16: Article number 954.

https://doi.org/10.1186/s12889-016-3599-3

PMid: 27613102 PMCid: PMC5016860

25. Torsheim T, Eriksson L, Schnohr CW, Hansen F, Bjarnason T, Valimaa R. Screen based activities and physical complaints among adolescents from the Nordic countries. BMC Public Health 2010; 10:324-31.

https://doi.org/10.1186/1471-2458-10-324

PMid: 20534116 PMCid: PMC2904715

26. Rosen LD, Lim AF, Felt J, et al. Media and technology use predicts ill-being among children, preteens and teenagers independent of the negative health impacts of exercise and eating habits. Computer Human Behavior 2014; 35:364-75. https://doi.org/10.1016/j.chb.2014.01.036 PMid: 25717216 PMCid: PMC4338000

27. Kraut R, Patterson M, Lundmark V, Kiesler S, Mukophadhyay T, Scherlis W. Internet paradox: A social technology that reduces social involvement and psychological wellbeing? American Psychologist 1998; 53(9): 1017-31. https://doi.org/10.1037/0003066X.53.9.101 7

PMid: 9841579
28. Wastlund E, Norlander $\mathrm{T}$, Archer $\mathrm{T}$. Internet blues revisited: replication and extension of an Internet paradox study. Cyberpsychology \& Behavior 2001; 4:38591.

https://doi.org/10.1089/1094931013002102 95

PMid: 11710264

29. Meena PS, Soni R, Jain M, Paliwal S. Social networking sites addiction and associated psychological problems among young adults: A study from North India. Sri Lanka Journal of Psychiatry 2015; 6(1): 14-6.

https://doi.org/10.4038/sljpsyc.v6i1.8055

30. Foley LS, Maddison R, Jiang Y, Marsh S, Old T, Ridley K. Pre-sleep activities and time of sleep onset in children. Pediatrics 2013; 131:276-82.

https://doi.org/10.1542/peds.2012-1651 PMid: 23319532

31. Furthner D, Ehrenmueller M, Lanzersdorfer R, Halmerbauer G, Schmitt K, Biebl A. Education, school type and screen time were associated with overweight and obesity in 2930 adolescents. Acta Paediatrica 2017; 107(3): 517-22. https://doi.org/10.1111/apa.14149 PMid: 29131386

32. Dennison BA, Erb TA, Jenkins PL. Television viewing and television in bedroom associated with overweight risk among low-income preschool children. Pediatrics 2002; 109(6), 1028-35. https://doi.org/10.1542/peds.109.6.1028 PMid: 12042539

33. Robinson TN. Television viewing and childhood obesity. Pediatric Clinics of North America 2001; 48(4): 1017-25. https://doi.org/10.1016/S00313955(05)703 54-0

34. Ray M, Jat KR. Effect of electronic media on children. Indian Pediatrics 2010; 47: 561 .

https://doi.org/10.1007/s13312-010-0128-9 PMid: 20683108 